\title{
Assessment of the influence of wastewater control options on Tietê River water quality
}

\author{
M. M. Buzzella ${ }^{1}$, K. Albertin ${ }^{2}$, W. Kreutzberger ${ }^{2}$, \\ A. Fortin ${ }^{1} \&$ S. Leifert ${ }^{3}$ \\ ${ }^{I} \mathrm{CH} 2 \mathrm{M}$, Brazil \\ ${ }^{2} \mathrm{CH} 2 \mathrm{M}$, USA \\ ${ }^{3}$ SABESP, Brazil
}

\begin{abstract}
Monitoring results from the Tietê River, located in the extremely populated Metropolitan Region of São Paulo (MRSP), have consistently indicated poor water quality. Untreated wastewater, discharges from wastewater treatment plants (WWTPs), and industrial and diffuse pollution are considered the primary pollution sources. Current practices are insufficient to meet water quality requirements established by law. Therefore, the effect of proposed improvements at five major WWTPs and the expansion of the sewage collection system, together with optimistic and realistic control scenarios of the other sources of pollution through 2040, were analysed to improve water quality. A linked PCSWMM/HECRAS framework was used to predict long-term watershed flows, pollutant loading and instream response to capture the impacts of discharges during low flow periods and of diffuse source loadings during wet period. Pollution control scenarios were developed, taking into consideration the variety of socio-economic residential areas, population growth, planned sewage service expansion, and strategic planning. Results from 2040 showed the importance of high quality sewage treatment, mainly as a result of nutrient removal. Model results were evaluated at key locations to assess water quality standards compliance on a daily basis. The optimistic scenario showed that improvements in water quality can occur and many of the water quality standards can be met. This assessment will be a valuable instrument to guide the decision-making process in establishing the sequence of actions and investments at WWTPs.
\end{abstract}

Keywords: diffuse pollution, untreated wastewater, HEC-RAS, integrated planning, water quality, watershed modelling, PC-SWMM. 


\section{Introduction}

The Metropolitan Region of São Paulo (MRSP), Brazil is the most populous urban area in the Southern Hemisphere with around 22 million inhabitants. The stretch of the Tietê River and its tributaries through the MRSP are heavily impacted by pollutant loading from the sanitary discharge from urban areas, industrial facilities and stormwater runoff. The Tietê River is the main river that runs through the MRSP and has consistently indicated poor water quality related to low dissolved oxygen (DO), high biochemical oxygen demand (BOD), nutrients, and bacteria levels.

Currently, the main pollutant loadings to the river come from discharges of untreated sewage. In 2010, around the Upper Tietê Basin, where this study was conducted, approximately $37 \mathrm{~m}^{3} / \mathrm{s}$ of sewage were generated. About 80 percent of this sewage was collected, with only 40 percent conveyed to Waste Water Treatment Plants (WWTPs) and the remaining discharged into the water bodies without any treatment. Most of the sanitation system in the MRSP is provided by the Companhia de Saneamento Básico do Estado de São Paulo S.A (SABESP), which operates five main WWTPs in the area. According to SABESP's measurements in 2010, these WWTPs treated around $16 \mathrm{~m}^{3} / \mathrm{s}$ of the $29 \mathrm{~m}^{3} / \mathrm{s}$ generated in its operational area (78 percent of the total area). The remaining wastewater depends on small systems operated by SABESP and on five municipalities that have autonomous sanitation systems around the study area. Some of these municipalities convey all or part of their sewage to SABEPS's WWTPs, while others have their own WWTPs.

The collection system and conveyance of the WWTPs have been gradually increasing in the area. SABESP's goal is to achieve 95 percent collection and treatment between 2024 and 2029.

Currently, WWTPs in SABESP's main collection system have only secondary treatment, discharging high amounts of ammonia and nutrients to nearby water bodies. Moreover, some of them do not remove organic matter effectively introducing high levels of BOD to the river. Therefore, apart from increasing the capacity of the WWTPs to achieve the demands in 2025, SABESP is planning to upgrade and modernize its five largest WWTPs.

In Brazil, WWTPs are regulated under CONAMA Resolution 430 of 2011, while São Paulo State is regulated by State Decree 8468 of 1976 . The laws require a minimum level of treatment to improve the quality of effluent, regardless of consideration of water quality of the receiving bodies. The river water quality standards are found in CONAMA Resolution 357 of 2005 for Brazil and in Decree 8468 of 1976 for São Paulo State. Both regulations contain the classification of water bodies and environmental guidelines for the environment goals to be achieved. These laws also provide progressive interim goals to be completed. Moreover, São Paulo State Decree 10755 of 1977 classifies all rivers in the state as the main tributaries of the Upper Tietê Basin in the urban metropolitan area and Tietê River as Class 4. Immediately after the transition from urban to rural areas, the river classification switches from Class 4 to Class 2, which has higher water quality targets (fig. 1). 
The sewer master plan of the MRSP of 2010 (PDE-10) was the last plan to be developed [1]. The PDE-10 reviewed all targets in the light of new trends of population growth and migration and updated sewer flow estimates. In addition, it considered the continuity of current processes and technologies of the five WWTPs in SABESP integrated system, with the possibility of short-term changes in the management of produced sludge. These guidelines, adopted by the PDE-10, were established for a 2030 horizon using a stationary QUAL2E model without observing the impact of WWTPs effluent in the river water quality. This previous model estimated DO, BOD, TN, TP and coliforms but did not consider the limitations required by law.

In order to move a step forward, SABESP engaged $\mathrm{CH} 2 \mathrm{M}$ and a local joint venture partner, JNS, to conduct preliminary engineering and planning for upgrading/modernizing the existing WWTPs. $\mathrm{CH} 2 \mathrm{M}$ is developing a comprehensive assessment of pollutant loading and water quality response of Tietê River. The objective of this assessment is to contribute to the improvement of the Tietê River quality by identifying and quantifying the various sources of pollution and determining the most cost efficient and effective sewage related pollutant control strategies.

A 1-dimensional dynamic, daily time step continuous simulation modelling system was used to predict long-term water flow, loading and instream processes to capture the impacts of discharges during low flow periods and diffuse source loadings, which come into the system during rain events. This allows an assessment of frequency and duration of poor water quality conditions and impacts from interactions, which occur over many days or weeks such as degradation of organic material in urban runoff.

The model framework was required to quantify loading from five different pollutant sources: 1) discharges from SABESP's five WWTPs; 2) untreated sewage; 3) direct industrial pollution; 4) diffuse pollution; and 5) pollution from the municipalities that are not operated by SABESP, and finally, calculate their influence on the water quality of Tietê River.

\section{Study area and available data}

The study area includes the Alto Tietê basin, about $5,600 \mathrm{~km}^{2}$ in size. The Tietê River is approximately $140 \mathrm{~km}$ long between the upstream boundary, at the Estaleiro flow gage, and Rasgão Dam at downstream end of the study area (fig. 1).

The Tietê River has a highly channelized, trapezoidal section, through the urban São Paulo area, and is less than 100 meters wide over most of its length (base width is between $45 \mathrm{~m}$ and $65 \mathrm{~m}$ ). The Tamandauateí and Pinheiros Rivers, which are the Tietê River's main tributaries, are channelized as well. The Juqueri River, together with the upper part of Tietê River, have the only natural segments.

The model domain included only the river components in the basin, treating reservoirs on the tributaries as headwater inputs.

The Pinheiros River flows in its natural direction towards the Tietê River during dry periods and is reversed by means of pumps in Traição and Pereira 
towards Billings Reservoir during wet weather periods. The Guarapiranga Reservoir overflow is always conveyed to Billings Reservoir, by the Pinheiros River reversion, which discharges outside the basin. Therefore, the basins of these two reservoirs were not considered in the model domain, as they never drain into Pinheiros River and consequently Tietê River (fig. 1).

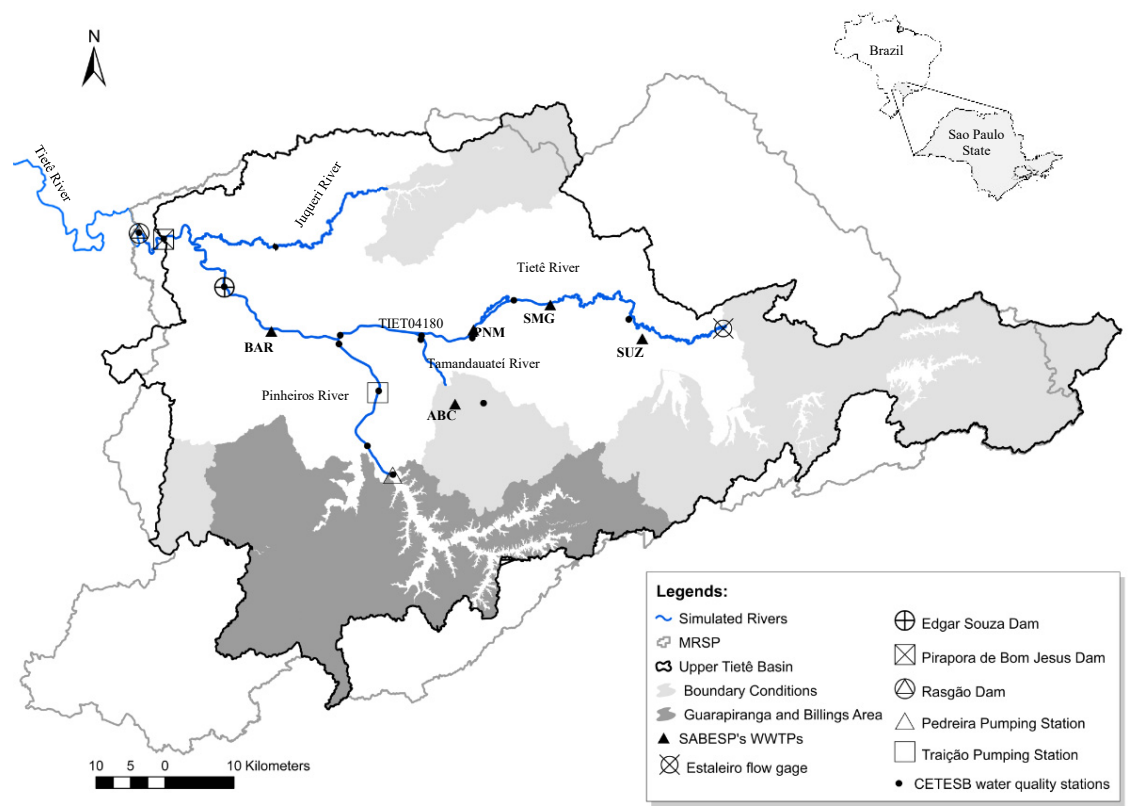

Figure 1: Study area and model domain.

There are a few minor impoundments along the Alto Tietê basin with the largest being Pirapora de Bom Jesus Reservoir near the downstream extent of the study area. With the exception of this last one, the instream impoundments are small with short retention times and were modelled as portions of the river with DO inputs as necessary to account for reaeration at the spillways.

There are few flow gages along the river. The primary gages measure discharges at the three largest dams, Edgar Souza, Pirapora de Bom Jesus, and Rasgão and are measured hourly. Moreover, there are seven daily stage measurements along the rivers, together with some flow stage (FS) curves.

Water quality measurements along the river are collected at a few strategic points on a bimonthly frequency by CETESB [2], which is responsible for instream water quality monitoring in São Paulo State (fig. 1). Review of these measurements for the study did not show statistical differences during the last years, presenting similar amount of concentrations since 2009.

The major contribution of pollutants to Alto Tietê is likely to come from nonpoint sources (NPS), composed of diffuse pollution and untreated wastewater in the watershed. This is mainly associated with land use, which directly influences the amount of pollutants that accumulate and is washed off during rainfall events. 
Moreover, socio-economic conditions are related to sewage concentration, low incomes are reflected in higher concentrations while high incomes in lower concentrations.

Land use data was obtained from the Empresa Paulista de Planejamento Metropolitano S.A. (EMPLASA) from 2010 and was combined with land cover data developed by the Environmental Department of São Paulo State.

SABESP provided the expansions of the WWTPs for the optimistic scenario for 2010 and 2040 conditions as presented in table 1 .

Table 1: $\quad$ SABESP WWTPs capacities.

\begin{tabular}{|c|c|c|}
\hline SABESP WWTPs & 2009/2010 capacity $\left(\mathrm{m}^{3} / \mathrm{s}\right)$ & 2040 capacity $\left(\mathrm{m}^{3} / \mathrm{s}\right)$ \\
\hline ABC & 1.8 & 6.4 \\
\hline Barueri (BAR) & 9.7 & 24.3 \\
\hline Parque Novo Mundo (PNM) & 2.5 & 6.3 \\
\hline São Miguel (SMG) & 0.8 & 4.7 \\
\hline Suzano (SUZ) & 1.0 & 2.4 \\
\hline
\end{tabular}

\section{Methodology}

\subsection{Model selection}

The physical characteristics and water quality parameters can be assumed to be vertically and transversally uniform throughout the river. For this reason, a 1-dimensional (1-D) receiving water model can be used. Reservoirs along Tietê river present low retention times and can be treated as wide portions of the river consistent with a 1-D model, but with the input of additional DO due to turbulence as the water runs down the spillways. For the purpose of this evaluation, the Pirapora de Bom Jesus Reservoir was also simulated with a 1-D model since the primary focus was not a detailed estimate within the reservoir, but on how concentrations change from the inflow of the reservoir to the outlet.

Since the receiving model is dependent on the watershed model for inputs, the capabilities of the watershed model follows the input requirements of the receiving water model. This includes simulation of oxygen demanding materials and nutrient species from a diverse set of land uses on a daily basis and at a moderately fine spatial scale. Furthermore, the watershed model must have the ability to represent the complexity of the land uses and the presence of slums in MRSP.

Based on the objectives of the project, the modelling tools were required to be well developed and supported, commonly used, and capable of simulating BOD, nutrients, and bacteria levels at a spatial and temporal level appropriated to the amount of data available. A linked system of the refined PC version of EPA's Stormwater Management Model (PCSWMM) and the Hydrologic Engineering Center River Analysis System (HEC-RAS) modelling tools was developed to calculate watershed hydrology and pollutant loading to the Tietê River system as 
well as pollutant transport and water quality response within the main stream of the Tietê River and its tributaries. PCSWMM is a well-established and wellsupported watershed model, which can simulate runoff from a variety of land use types. The HEC-RAS model, a standard in instream hydraulic simulation, has been recently revised to include pollutant fate and transport.

Non-point pollution sources were considered in PCSWMM, while point sources were considered in HEC-RAS (fig. 2).

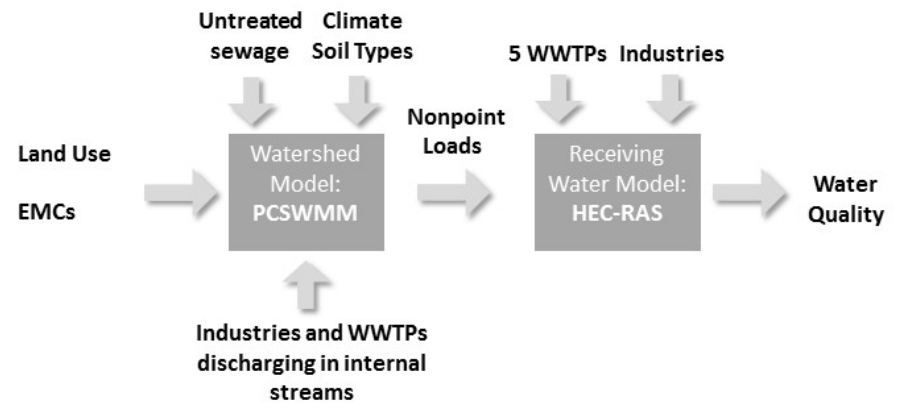

Figure 2: Link between watershed and receiving models.

The models can be used to either directly estimate the amount of pollutant loading from the watershed; or by event mean concentrations (EMCs), which may be applied to the predicted runoff volumes to estimate pollutant loadings. For this study, pollutant loadings were calculated using modelled flow and EMCs in separate spreadsheets since there was no available watershed loading data for calibration. These EMCs reflect the activities that occur on a specific land use. Twenty-three land uses were identified for this area; twelve for urban areas and eleven for rural areas. In the urban areas six different typologies based on socioeconomic conditions and the relation between public and private areas were identified. The EMCs for each land use within a subbasin were specified initially according to literature review. Moreover, depending on the average income of each subbasin, mean concentrations were considered specified the untreated flow. Both EMCs and untreated flow characteristics were adjusted during calibration.

\subsection{Model development}

The main data used to set up the watershed model were elevation data, hydrologic network, land characteristics such as soil types and land uses, boundary conditions information, meteorological data, daily precipitation and evaporation. A total of 381 subbasins were identified in the area with average size of $14.8 \mathrm{~km}^{2}$.

The receiving water model consists of a hydrodynamic module and a water quality module. The hydrodynamic module was set up, calibrated, and run prior to development and calibration of the water quality module.

The setup of the hydrodynamic module of the receiving water model consisted of defining the river geometry, particularly the flow area and slope of the riverbed, 
modeling hydraulic structures located within the Tietê River, and defining boundary conditions and input files. The water quality setup required segmentation of the river into computational cells as well as specification of boundary conditions and input files.

Water temperature at the upstream and lateral boundaries was based on the best available monitoring data at or near the associated dam discharges. Concentrations of nutrients and other water quality constituents associated with the upstream boundary conditions were based on available instream data collected near the associated upstream boundary.

The watershed and receiving water models were not integrally linked but were run separately with the output files from the watershed model post-processed to generate model input for the receiving water model.

\subsection{Model calibration}

To perform the calibration, the hydrological year from October 2009 until September 2010 was chosen due to being the period with average and representative precipitation conditions (wet and dry periods and annual mean) according to historical records and with the most complete available data. Water quality has not changed significantly since this so it was considered as the current situation for this study. The validation period was chosen from February until September of 2011. Within this period, a calibration of the watershed model (independent of the receiving water model) could not be performed since runoff data were not directly collected and monitored. Unsteady flow calibration was performed separately from water quality (fig. 3). The receiving water model was calibrated and verified for dry weather conditions, based on a period with no storm water runoff. After the receiving water model was calibrated for low flow, nonrunoff conditions, the watershed model was calibrated by adjusting watershed loadings based on results of the calibrated receiving water model and instream observations.

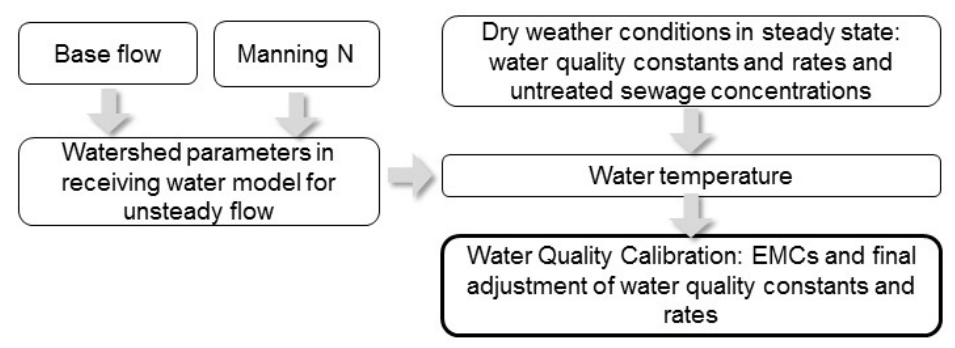

Figure 3: Model calibration procedure.

Water quality calibration was based on bimonthly instantaneous measurements in the Tietê River and its principal tributaries. The lack of frequent instream data demanded a calibration based on statistical data, observing dry (June until August) and wet (December until February) weather conditions trends, and applying visual 
criteria as well. Results were analysed for each water CETESB's water quality station (fig. 1), comparing observed means obtained during dry weather calibration phase along the Tietê River (fig. 4).
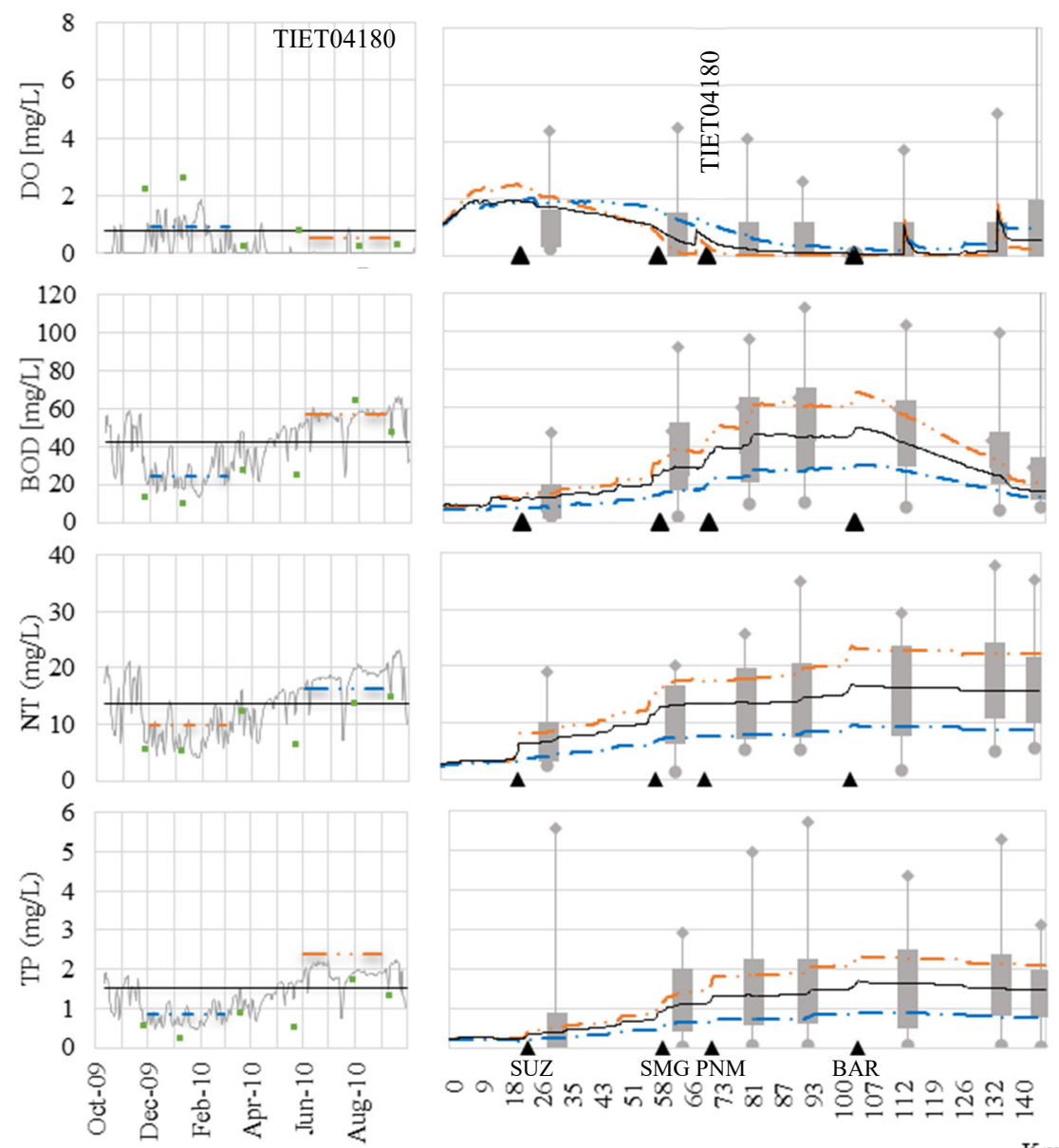

ด๓

$\mathrm{Km}$

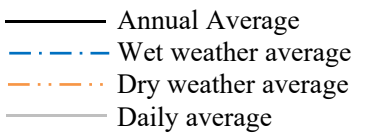

Max
Q3
Q1
Min

- SABESP WWTPS

- TIE04180 instantaneous measurements (CETESB)

Figure 4: Calibration results at Station TIET04180 and mean longitudinal profile of Tietê River.

The Nash-Sutcliffe efficiency metric, Nash and Sutcliffe [3] was used to asses unsteady flow calibration and validation, presenting values of 0.8 , which is very good according to Moriasi et al. [4]. The R-squared coefficient of determination 
was applied as well. The calibration and validation resulted in values of 0.8 or better considered as "good" according to Duda et al. [5].

\section{Future scenarios}

Pollution control scenarios were developed, taking into account the variety of socio-economic residential areas in the Sao Paulo super-metropolis, available data on population growth, planned sewage service expansion and strategic planning through 2040 provided by SABESP and cities in the surrounding area of the MRSP. The assessment results quantified pollutant loads by source category, calculated water quality under current and future conditions, and the effect of improvements performed at the WWTPs and the expansion of the sewage collection system. For the realistic scenarios historical trends were utilized. For the optimistic scenario, planned and potential possibilities were considered and evaluated. For example, the opportunity of implementing mitigation meassures, where possible, for the diffuse pollution were incorporated into the optimistic scenario.

The effluent quality of the WWTPs in the realistic scenario was based on traditional secondary treatment, considering a percentage of removal as stated in PDE-10 [1]. The optimistic scenario considered advanced treatment applying removal coefficients to the different constituents The wastewater characteristics for the realistic and optimistic scenarios are presented in table 2.

Table 2: $\quad$ SABESP WWTPs scenarios.

\begin{tabular}{|l|c|c|}
\hline Constituent & $\begin{array}{c}\text { Optimistic } \\
\text { concentration (mg/l) }\end{array}$ & $\begin{array}{c}\text { Realistic } \\
\text { percent removal }\end{array}$ \\
\hline $\mathrm{DO}$ & 1 & - \\
\hline $\mathrm{BOD}$ & 5 & 95 \\
\hline $\mathrm{NH}_{4}$ & 0.5 & 20 \\
\hline $\mathrm{TKN}$ & 2 & 20 \\
\hline $\mathrm{NO}_{2}$ & 0 & 20 \\
\hline $\mathrm{NO}_{3}$ & 4.5 & 20 \\
\hline $\mathrm{P} \mathrm{Organic}$ & 0.009 & 30 \\
\hline $\mathrm{PO}_{4}$ & 0.099 & 30 \\
\hline
\end{tabular}

\section{Results and discussions}

For current conditions, model results showed that in SABESP's operations areas, untreated sewage together with the discharge of the five WWTPs, is generating 70 percent of the organic matter. This could potentially be reduced by 2040 to 26 percent with implementation of the controls specified in the optimistic scenario. As the realistic scenario considered traditional secondary treatment without nutrient removal, the amount of generated TN is increased by 2040 because the removal does not compensate for the population growth. For the optimistic 
scenario, the influence of SABESP can be reduced to 55 percent. Although in 2010 diffuse pollution has around 15 percent of influence in pollution generation, in the future scenarios it becomes the main source of pollution. Finally, industrial pollution can be neglected in comparison to the other sources of pollution in current situation and future scenarios (fig. 5).

The only target to be achieved in Class 4 waters is DO. Preliminary simulation results showed that on average, for the optimistic scenario, this target is fully achieved. While for the realistic scenario, after the Barueri WWTP (BAR) discharge, this target is not achieved (fig. 6).

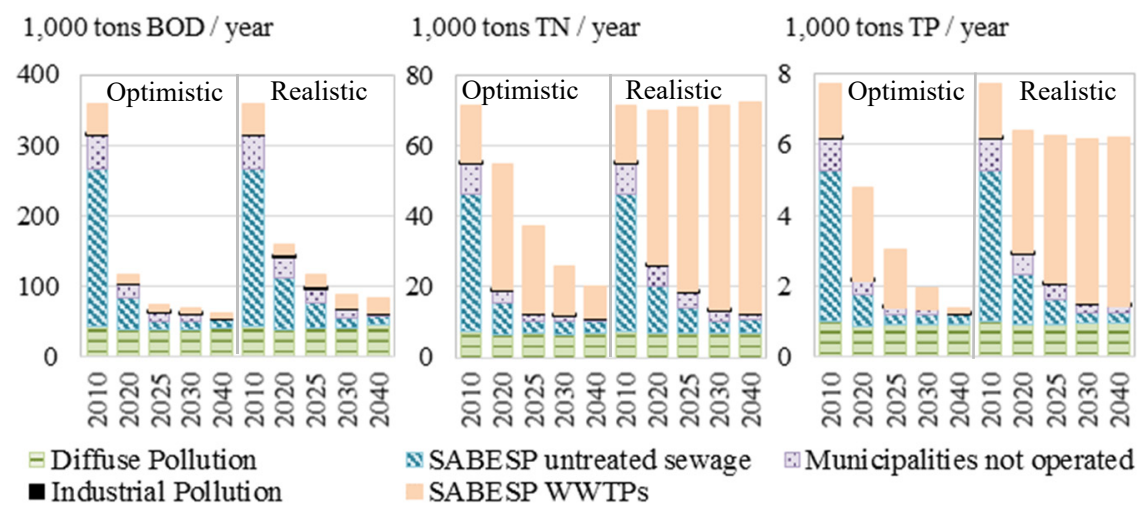

Figure 5: Generated loads per source of pollution.

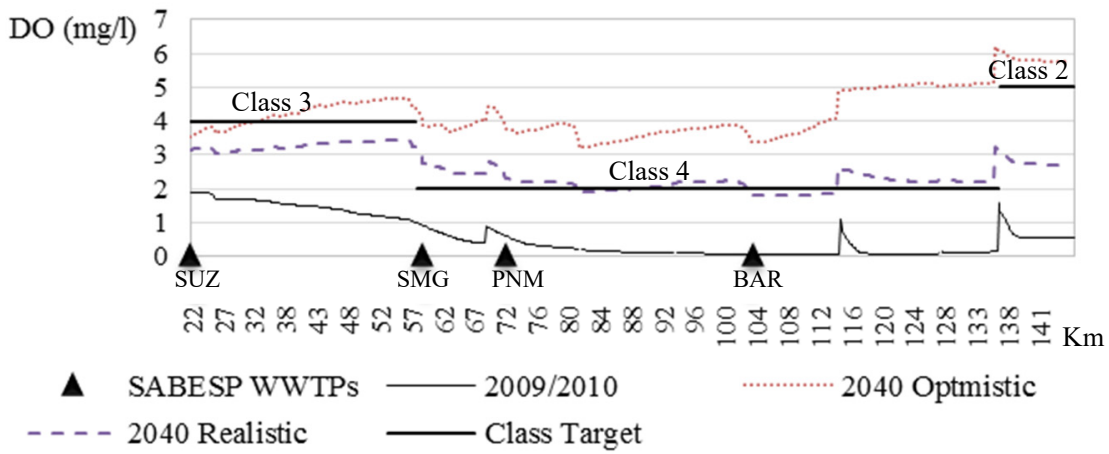

Figure 6: Longitudinal profile of Tietê River, mean DO concentrations obtained in preliminary simulations of concentrations compared to the targets.

Special attention was given to the section of the river in which the classification changes from Class 4 to Class 2 . The constituents that have restrictive targets are $\mathrm{DO}, \mathrm{BOD}$, ammonia, and TP. In the current situation, preliminary simulations showed that only the ammonia target is reached during wet periods (5.8 percent exceeded during the whole year), while all of the other constituents exceeded their 
standards. For TP, neither on the realistic nor the optimistic scenario achieved the water quality target (fig. 7).

During dry weather, the period in which the influence of wastewater can be observed, DO and ammonia targets are fully compliant while BOD is almost fully achieved with 95 percent of compliance in the optimistic scenarios of 2040. However, in the realistic scenario, DO and ammonia targets are never reached, while BOD has 60 percent compliance (fig. 7).

The optimistic scenario shows that improvements in water quality can occur and many of the water quality standards can be met. This assessment will be a valuable instrument to guide the decision-making process in defining and establishing the sequence of actions and investments at the SABESP WWTPs.

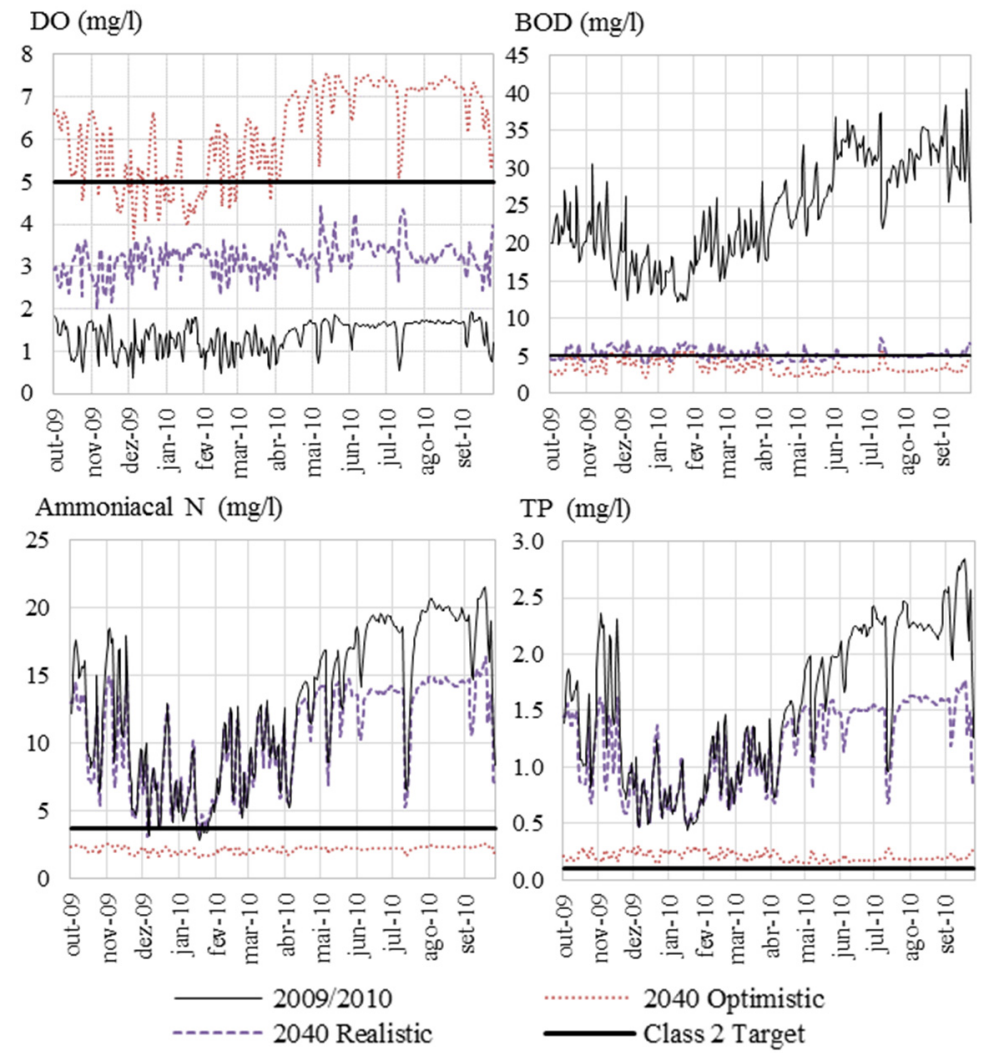

Figure 7: Preliminary simulations of concentrations compared to the targets in class 2 section in Tietê River.

\section{Conclusions}

For the first time in the MRSP, an unsteady-flow water quality model has been used to focus on improving water quality of Tietê River and understanding 
seasonal effects of pollutant discharges. The calibration performed by weather conditions trends and visual criteria (due to lack of robust water quality data) yielded satisfactory results. Establishment of EMCs to understand the impact of diffuse pollution in the area was performed based on an international literature review. Adapting these values to better represent conditions in the MSRP may be done in the future to establish local values. Results showed that the phosphorous target is never achieved even in the most optimistic scenario. In this manner, reformulation of water quality regulations should be considered.

Simulation results provided an understanding of the relative importance of the different sources of pollution. In the current situation, untreated sewage in SABESP's operation area together with the discharge of the five WWTPs are responsible for about 70 percent of the pollution discharge in the Upper Tietê Basin. Nevertheless, in future scenarios, even with levels of pollution highly reduced, the compliance to water quality targets would not be fully achieved, with the most critical conditions being the wet season. Therefore, once the expansion of the collection system is completed and diffuse pollution becomes the main source of pollution in the area, focus should be on mitigation and control of the diffuse pollution. Future simulation area should be extended downstream in order to determine sections of the river where compliance targets are achieved.

Several simulations should be performed combining optimistic and realistic future scenarios of the different sources of pollution, in order to support the decision-making process in establishing the sequence of actions and investments at WWTPs. The importance of properly collecting and treating wastewater in terms of organic matter is unquestionable. Regarding ammonia- $\mathrm{N}$, traditional secondary treatment did not achieve the expected targets, while innovative treatments superseded the expectations being possible to think of blending, establishing the portion of innovative and traditional treatment at the five WWTPs.

\section{References}

[1] COBRAPE \& CONCREMAT, Plano Diretor de Esgotos da Região Metropolitana de São Paulo, SABESP: São Paulo, 2010.

[2] CETESB, http://aguasinteriores.cetesb.sp.gov.br/publicacoes-e-relatorios/

[3] Nash, J.E. \& Sutcliffe, J.V., River flow forecasting through conceptual models: Part 1- A discussion of principles. Journal of Hydrology 10(3), pp. 282-290, 1970.

[4] Moriasi, D. N., Arnold, J. G., Van Liew, M. W., Bingner, R. L., Harmel, R. D. \& Veith, T. L., Model evaluation guidelines for systematic quantification of accuracy in watershed simulations. Transactions of the ASABE, 50(3), pp. 885-900, 2007.

[5] Duda, P. B., Hummel, P. R., Donigian Jr., A. S. \& Imhoff, J. C., BASIN/HSPF: Model use, calibration and validation. Transactions of the ASABE, 55(4), pp. 1523-1547, 2012. 